\title{
Mensagem do Presidente da ABPol
}

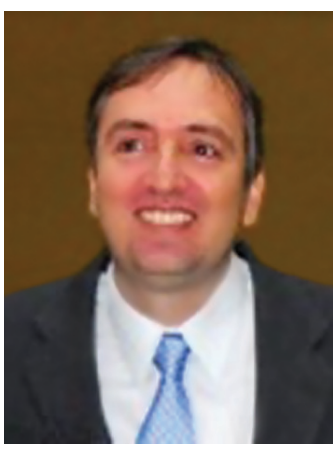

O principal objetivo da ABPol é atuar junto a empresas e instituições de ensino e pesquisa, viabilizar o desenvolvimento na área dos materiais poliméricos e difundir de forma continua os conhecimentos acadêmicos, tecnológicos, científicos em relação aos Polímeros.

A participação em feiras, realizações de reuniões, cursos, congressos, seminários promovem a troca e atualização constante das informações, uma vez que proporciona o contato direto entre os pesquisadores e profissionais da área.

O Congresso Brasileiro de Polímeros é considerado uma das principais realizações da Associação Brasileira de Polímeros, que busca melhoria constante para atender às necessidades do setor de Polímeros. É uma das mais importantes ferramentas na disseminação da informação sobre o setor e promove o intercâmbio entre esses profissionais.

O $11^{\circ}$ Congresso Brasileiro,assim como as demais edições, contará com a participação de diversos expositores e patrocinadores das mais tradicionais empresas existentes atualmente na área de Polímeros e de pesquisadores renomados na área.

No encerramento do $11^{\circ} \mathrm{CBPol}$, no dia 20 de outubro, ocorrerá a posse da nova diretoria da ABPol para o biênio 2012/2013.

Contamos com a presença de todos no $11^{\circ} \mathrm{CBPol}$ e nos vemos em Campos do Jordão. Até lá.

Dellyo Ricardo S. Álvares

\section{EDITORIAL}

Prezados leitores, é com imenso prazer que estamos entregando a vocês a Edição 03/2011 de nossa revista. Lembro a todos colaboradores que a partir deste ano a Edição Especial passará a ser a Edição 05/2011. Ampliar o número de Edições de nossa revista foi uma conquista de todos que nos tem brindado com excelentes artigos e que permitiram que atingíssemos o Fator de Impacto em 2010 igual a 0,436. O reconhecimento, através dos financiamentos pelo CNPq e FAPESP, permitiu que pudéssemos melhorar e manter o nosso sistema de submissão eletrônica, a regularidade na entrega dos exemplares impressos. A continuidade deste trabalho só será possível se cada pesquisador associado transmitir e informar seus colaboradores que hoje temos um veículo reconhecido nacional e internacionalmente para divulgação de nossos resultados e avanços no campo das pesquisas na área da Ciência dos Polímeros. Insisto que uma forma simples de fazer isto é através da citação dos trabalhos publicados em nossa revista nos artigos submetidos a revistas arbitradas internacionais.

Finalmente quero registrar um agradecimento especial ao nosso corpo de revisores que tem garantido a qualidade dos artigos publicados e a nossos colaboradores que aumentaram o número de envios de trabalhos permitindo que já tenhamos garantida a publicação da revista até a Edição 04/2012. 